\title{
Analysis of the Urban Expansion for the Akure, Ondo State, Nigeria
}

\author{
E.E. Eke ${ }^{1, a}$, M.A. Oyinloye $e^{2, b^{*}}$, I.O. Olamiju ${ }^{3, c}$ \\ ${ }^{1,2,3}$ Department of Urban of Urban and Regional Planning, School of Environmental Technology, \\ Federal University of Technology, Akure, Nigeria

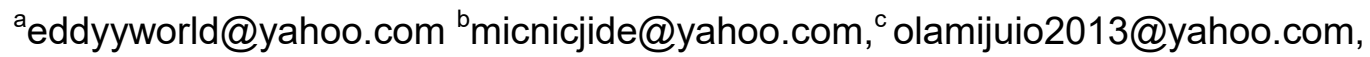

\begin{abstract}
Keywords: urban expansion, Landsat images, landuse/landcover, population, Akure.
\end{abstract}
\begin{abstract}
African cities are experiencing uncontrolled expansion. The focus of this paper is to evaluate the impact of urban expansion on landuse types of Akure for the period of 1972 to 2009. In analyzing the urban expansion of the city, 1972 MSS, 1986 Landsat Thematic TM and Landsat Enhanced Thematic Mapper Plus ( $\left.\mathrm{ETM}^{+}\right)$images for 2002 and 2009 satellite image captured from google earth website were used in a post classification comparison analysis to map the spatial dynamics of landuse/ land cover changes and identify the urban expansion of Akure. Questionnaire was also used to determine the factors responsible for the expansion of Akure. The findings showed a rapid expansion in the built-up area of Akure from $1.00 \%$ in 1972 to $2.46 \%$ in $1986,2.46 \%$ in 1986 to $3.90 \%$ in 2002 with an annual growth rate of $10.63 \%$ and $3.66 \%$ due to increasing population of Akure within these periods respectively. Prediction made showed that the built-up of Akure would expand to $2.66 \%$ in 2022 . The study recommends review of the outdated 1980 master plan and development control mechanism that will guide the rapid expansion that had been accompanied by loss of vegetation in Akure.
\end{abstract}

\section{Introduction}

Africa now has a population close to 1.030 billion people, with $38 \%$ of these living in the cities. The rapid urbanization seems to be accompanied by high levels of concentration of urban population in very large cities [1]. In Nigeria, urbanization parameters progress at a phenomenal rate without any articulated policy to stem its tide. The dynamics of the scenario in Nigeria is typified by the fact that while less than $15 \%$ of the total population lived in cities of 20,000 or more population by 1950, 25 years later in 1975, this proportion increased to $23.4 \%$ and by 2000 , the proportion had increased $43.3 \%$. The prognosis is that by 2025 , more than half of the nation's population will live in urban centres [2]. This has its untold implications as the societal learning required to adapt rural institution to urban ones in the developing world became a crash course, leaving little or no room for adjustment [1]. [3] also affirmed that in many of these cities, pace of urban growth readily outpaces the capacity of metropolitan and planning authorities to provide basic services that include adequate sanitation, water and even food resource.

However, all of these growths have spatial implications which impinge on available of land for farming practices especially in cities where spaces are consistently being taken over and spatial frontiers expanded in the quest for urbanization. Given the above nexus, food resources now become essential but hard to find. In this regard, the physical and spatial change in urban areas with rural base can be a considerable challenge in metropolitan areas and a monumental one on continental scale [4]. Along with these challenges are climate change and food security nexus; these are potent problems in the African development saga which ecological and organic agriculture may help to mitigate, with a view to attain a balance in the living environment. It is on this point that urban planners and other environmental scientists have focused their attention on urban growth in order pattern in order to help understand, and potentially lower the negative effects of large -scale urbanization.

The aim of this paper therefore is to demonstrate the use of remote sensing and Geographical Information System (GIS) to evaluate the rate of urban expansion and its effect on landuse/landcover in Akure with a view to ensure environmental sustainability. The objectives are to: 
i. evaluate the lateral expansion of Akure city into adjoining rural lands between 1972, 1986, 2002 and 2009 using base map and remote sensing;

ii. predict the urban expansion of Akure by adopting the exponential growth model;

iii. evaluate the relationship between population growth and landuse pattern in the study area; and

iv. identify the major factors influencing the urban expansion using questionnaire survey method

\section{The Study Area}

The study area is Akure, the administrative capital of Ondo State. The city is located within Ondo State in the South Western part of Nigeria. It lies approximately on latitude $7^{0} 15^{1}$ North of the Equator and longitude $5^{0} 15^{1}$ East of the Greenwich Meridian. Akure is a medium- sized urban centre and became the provincial headquarter of Ondo province in 1939. It also became the capital city of Ondo State and a Local Government headquarters in 1976 (see fig. 1). The city's morphology has changed over time to assume its present status with its attendant land use problems, as experienced in similar medium sized urban centres in Nigeria. Akure is located approximately 700 kilometers South West of Abuja, the Federal Capital of Nigeria and about 350 kilometers to Lagos the former capital of Nigeria. The annual average temperatures range between 21.4 and $31.1^{\circ} \mathrm{C}$, and its mean annual relative humidity is about $77.1 \%$. It is located within the tropical rain forest region of Nigeria where rainfall is high throughout the year. In 1963, Akure had a population of 71,106 which increased to 109,253 by 1976 [5]. The rapidity of its development within forty years stemmed from the political status of the city which was initially a provincial headquarters later a state capital thus servicing as the seat of both local and state governments ever since; this accounted for the influx of people into the city for employment. In 1991, the population had risen to 239,124 [6] and by 2006 the population was put at 340,021 [7-8].

\section{Review of Literature}

Urban growth is being influenced by continued global economic integration and the struggle by countries- and indeed individual cities-to be competitive in the global market place. Managing urban growth has increased in both scope and complexity and has become one of the most important challenges [9]. In an increasingly urban world, almost half of the world's total population and nearly three-quarters of all Westerners live in urban areas. Merrill reported that rapid growth of cities and urbanization has been the key driver of Asia's dynamic growth and of the poverty reduction that has resulted [7]. The region's success is dependent on high levels of capital investment to create world class factories, rising productivity and openness to foreign exchange trade because minerals. UN-HABITAT pointed out that the third era of growth of cities and globalization as changing the relative competitiveness and opportunities for the growth of cities as well as better access to communication's technology, international capital markets, global production because of natural resources including metal and gemstone mine production [10]. William concluded that Chicago's growth in the $19^{\text {th }}$ century was impressive in the absence of any real natural advantages but recent growth is because of mine operations, all over the world cities and towns are expanding by natural increase and immigrations [11]. Two major urban features mark urban growth in Nigeria. The first is the intensification of land use with resultant modifications to the urban spatial structures within the already built-up parts of some cites and the second is the outward spread of the built-up parts of urban centres into rural areas [12]. According to them, the intensification of landuse in the urban area of Nigeria is a large feature of the pre-colonial urban centres. Growth by the outward expansion of the built-up area according to them has contributed largely to the evolution of the contemporary landuse pattern in most Nigeria rural and cities particularly the colonial towns and most rapidly growing pre-colonial areas. 


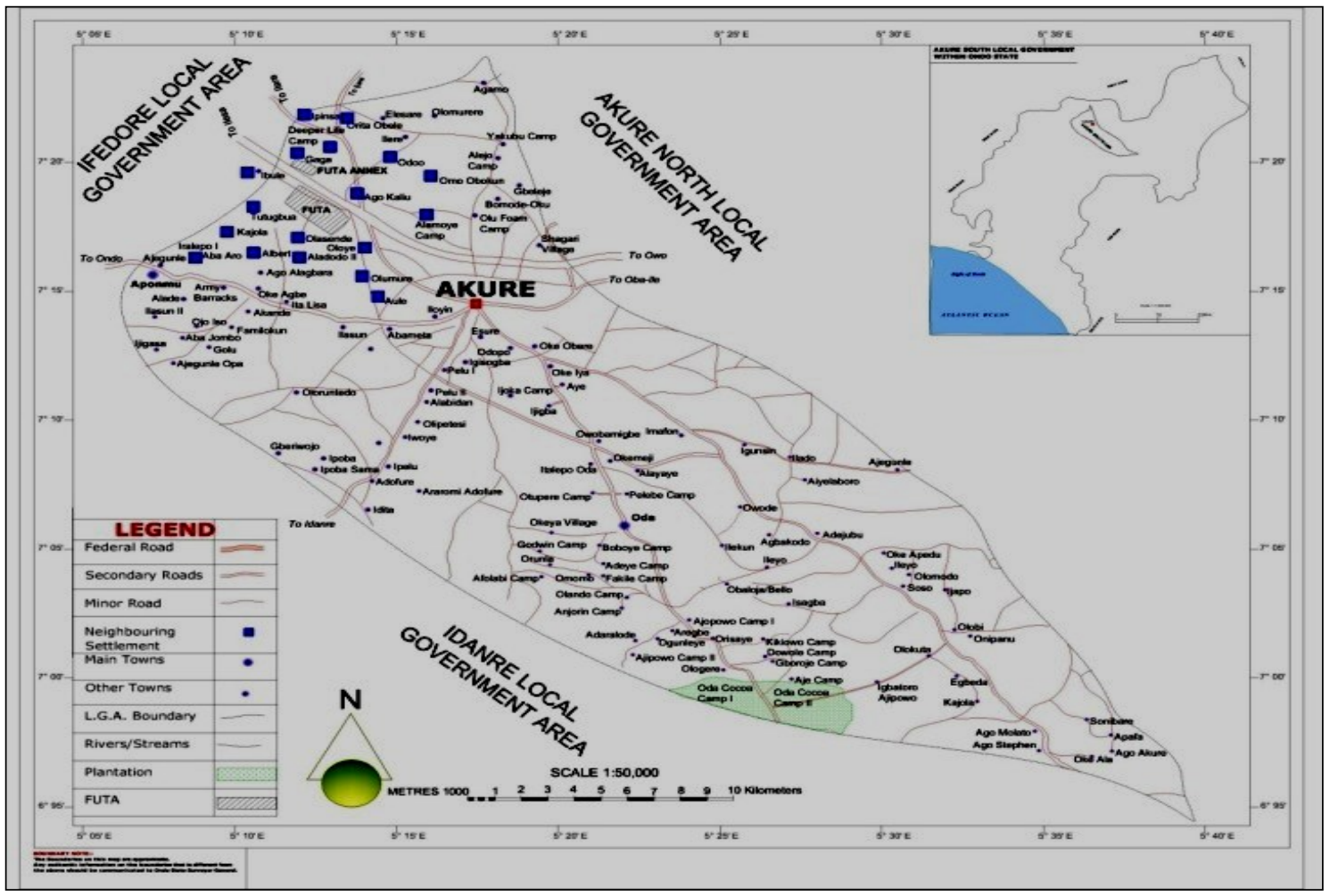

Figure 1. Map Showing the Location of the Study Area.

Several researchers have studied the growth and expansion of urban settlements. Elnazir analysed the nature, rate and location of urban landuse changes, urban built-up land was extracted from each of the images, overlaid on each other to obtain an urban expansion image [13]. These extractions were done on layers in the vector GIS environment and the result used to identify urban land change to obtain real time information. Sedighah used aerial photographs and satellites stereo images to provide an urban growth map [14]. Here, stereoscopic analysis was done on the satellite data using a second level classification procedure. A digitized map of the study area was incorporated in the stereo analysis to differentiate all areas with the known information. [15] used satellite images (ASTER, $\mathrm{EMT}^{+}, \mathrm{TM}, \mathrm{MSS}$ ) from different sensors to analyze growth was established using a data set compiled from interpreted aerial photography and IKONOS imagery. By the method of image interpretation and classification, the derivation of the extent of built-up areas was delineated for each of the set data.

Musaogwu incorporated remote sensing and GIS to create overlays of two or more independently produced classified images [8]. It can be used to detect changes, trend, location and amount of changes that have occurred. [16] used remote sensing to examine the changed pattern and used auxiliary data to project the land area of Tuni region into the year 2000. The approach was validated by two other methods including Causal modelling, cross-classification model and rating methods. He observes that human needs transform the land to different activities and that the quantifiable information of these dominant activities is necessary to develop future planning.

[1] used satellite images of 1978 and 1995 and updated topographic maps of 2003 to carry out the expansion of Ogbomoso town, Oyo, Nigeria. [17] used the GIS database to model the land use/cover change between 1984 and 2003 for Akwa Ibom State. The result showed that some urban centres had expanded into farmlands/fallow lands and the surrounding secondary forest. [18] analyzed satellite imageries of 1987 and 2004 for the Federal Capital Territory, Abuja for land use change. The imageries were characterized into five classes using maximum likelihood algorithm. The classes were vegetation, built-up, rock outcrop, water body and farm land. The analysis revealed that vegetation cover reduced by 85.22 per cent between 1987 and 2004. Again, the builtup area increased by 21.99 per cent and farm land increased by 0.14 per cent. 
The remote sensing applications are growing very rapidly with the availability of highresolution data from the state of the art satellites like IRS-LC/ID/P4, IKONOS, SPOT, QuickBird, and Landsat-TM/ETM ${ }^{+}$coupled with advancement in computer hardware and software applications. Spot for example, provides data with $10 \mathrm{~m}$ resolution giving more information of the growth area covered. The remote sensing satellites with high-resolution, coverage and revisit time to meet the growing applications needs.

\section{Data Acquisition and Method}

This study was interested in the evaluation of urban expansion in the study area. It also seeks to use the capabilities of Geographical Information System and remote sensing techniques to determine the rate of expansion in the study area. To achieve this, LandSat satellite images of the study area were acquired for three years: Landsat Multispectral Scanner (MSS) of 1972, Thematic Mapper (TM) of 1986 and Enhanced Thematic Mapper $\left(\mathrm{ETM}^{+}\right)$of 2002 while satellite image of Akure of 2009 was captured from Google website (http://www.googleearth.com). This satellite image of Akure as posted online on this website was imported Into GIS environment. These images were geometrically corrected and ground control points obtained through intensive ground surveys permitted the co-registration of all images to a Universal Transverse Mercator (UTM). All the images were made to pass through processes of image enhancement, georeferencing, re sampling, image classification and digitizing. A supervised classification was performed on false colour composites (band 4, 5 and7) into the following landuse/landcover classes: Built-up area, Dense vegetation, rock-outcrop, bareland/cultivation land and water bodies. The training sites selected was then used for the image classification procedure using the Maximum Likelihood Algorithm.

The Maximum Likelihood classification assumes that spectral values of training pixels are statistically distributed according to a 'multi-variate normal (Gaussian) probability density function' and is suitable for distinguishing features present in our tropical environment for best result in order to achieve the aim of the project. Therefore, Maximum Likelihood Algorithm was used to classify the images and identify changes that have taken place in the study area. Information collected during the field surveys was combined with the digital topographic map produced from aerial photograph of April 1963 and January 1965.

The questionnaire method was used to generate attribute data to further enhance our information on the study. For the purpose of this study, Akure was sub-divided into 20 residential neighborhoods namely Ilesha Road/Alaba Layout Residential Area, Okuta-Elerinla Residential Area, Akure High School/Kajola Residential Area, Ijapo Residential Area, Alagbaka Residential Area, Ala River Residential Area, Federal Housing Estate (Shagari Village) Residential Area, ObaIle Residential Area, Fanibi Layout/Lafe Residential Area, Oke-igan/Eruoba Residential Area, Isinkan/Ondo Road Residential Area, Oshinle Residential Area, Ijoka/Sijuwade Residential Area, Araromi/Isolo Residential Area, Oke-jebu Residential Area, Idi-agba Ijanikan Residential Area, Erekesan/Erekefa Residential Area, Ijomu Ilisa Residential Area [15]. Four (4) residential areas were then selected randomly from the 20 residential areas and each was further sampled on street basis. These four (4) residential areas are Erekesan/Erekefa, Ijoka/Sijuwade, Isinkan/Ondo Road, and Federal Housing Estate (Shagari Village) (see fig. 2). The questionnaires were allotted based on the number of buildings in the selected streets in each area and these were further shared between the streets. 


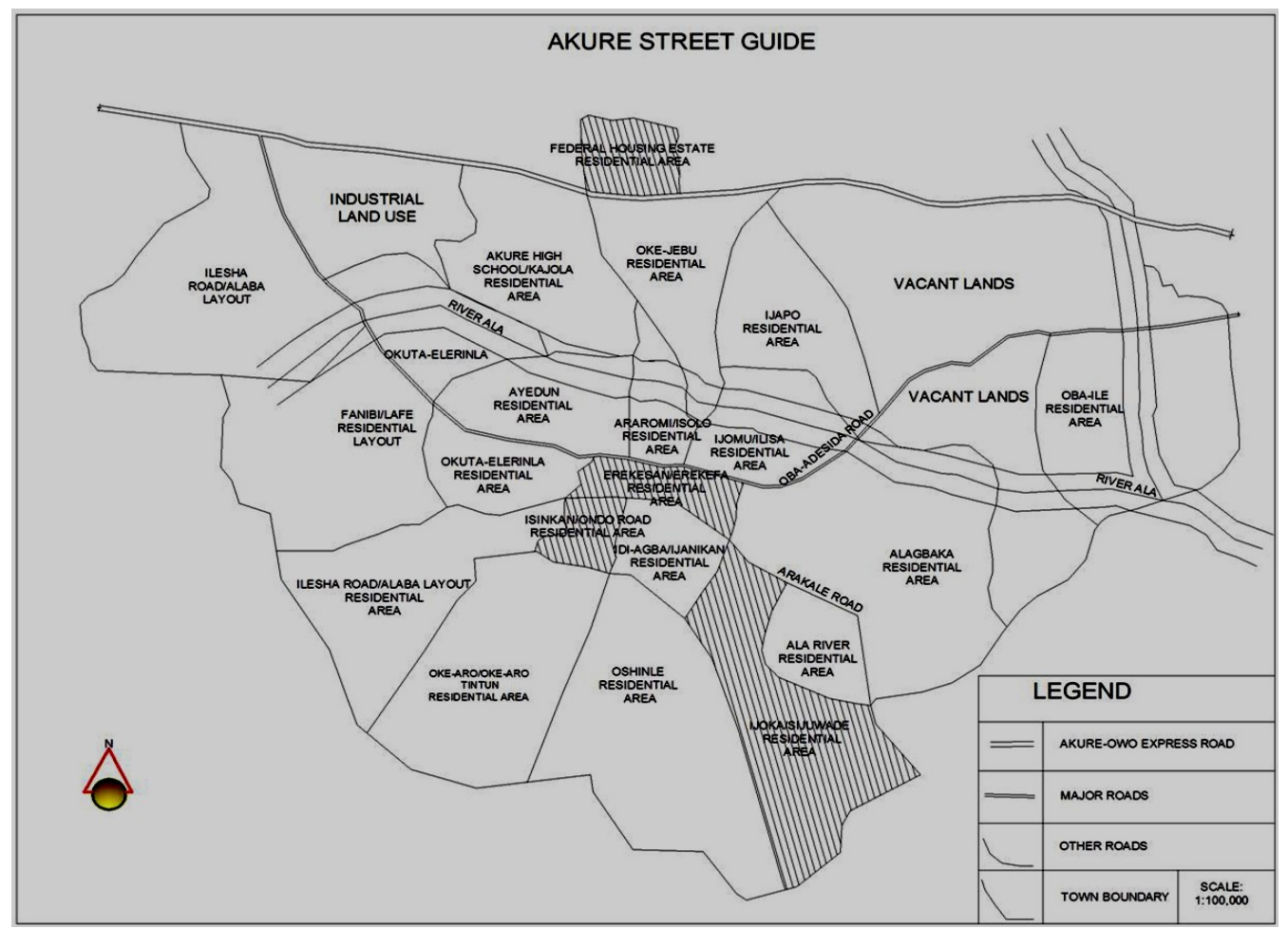

Figure 2. Map showing the 20 Residential and the 4 Sampled Residential Areas of Akure. Source: Adapted from [19]

Six hundred and four questionnaires were administered in all and out which three hundred and sixty one were retrieved giving a response rate of $60 \%$. By this reason the exercise is considered successful. Table 1 shows the residential and the number of questionnaires administered per resident.

Table 1. Questionnaire Administration Analysis.

\begin{tabular}{|l|l|c|c|c|}
\hline \multicolumn{1}{|c|}{$\begin{array}{c}\text { Residential } \\
\text { Areas }\end{array}$} & Sampled streets & $\begin{array}{c}\text { No. of } \\
\text { Buildings } \\
\text { in the } \\
\text { streets }\end{array}$ & $\begin{array}{c}\text { No. of } \\
\text { Questionnaires } \\
\text { Administered }\end{array}$ & $\begin{array}{c}\text { \% of } \\
\text { Questionnaire } \\
\text { Retrieved }\end{array}$ \\
\hline Erekesan/Erekefa & $\begin{array}{l}\text { Odo-Ikoyi and Car } \\
\text { streets }\end{array}$ & 291 & 145 & 49.8 \\
\hline $\begin{array}{l}\text { Isinkan/Ondo } \\
\text { Road }\end{array}$ & $\begin{array}{l}\text { Ajebamidele and } \\
\text { Gbogi }\end{array}$ & 104 & 80 & 76.9 \\
\hline Ijoka/Sijuwade & $\begin{array}{l}\text { Canaan land and } \\
\text { Sunday }\end{array}$ & 167 & 104 & 62.3 \\
\hline $\begin{array}{l}\text { Federal Housing } \\
\text { (Shagari Village) }\end{array}$ & $\begin{array}{l}\text { Presidential } \\
\text { Avenue and } \\
\text { Quarter guard }\end{array}$ & 42 & 32 & 76.2 \\
\hline Sub-total & & $\mathbf{6 0 4}$ & $\mathbf{3 6 1}$ & $\mathbf{5 9 . 8}$ \\
\hline
\end{tabular}

Source: Author's survey (2013)

The data collected using this medium was processed using Statistical Package for Social Scientists software (SPSS). Results obtained were presented in form of tables, charts and figures. The areas covered by the questionnaire include demographic factors responsible for urban expansion in the study area. All questions were carefully analysed and considered in addition to spatial information from GIS analysis to arrive at our conclusion. 


\section{Results and Discussion}

The lateral expansion of Akure city into adjoining rural lands between 1972, 1986, 2002 and 2009 using remote sensing as shown by GIS output are discussed below.

Fig. 3 shows that most part of the study area has been generalized as vegetation based on the fact that Akure has not started developing into a big city and the proportion of built-up area is small. Therefore, there is apparently less exploitation of the natural resources and most of the vegetation remains rain forest. In addition, the rock extracted from the map cannot categorically be classified as bare rock because some are expectedly covered by vegetation.

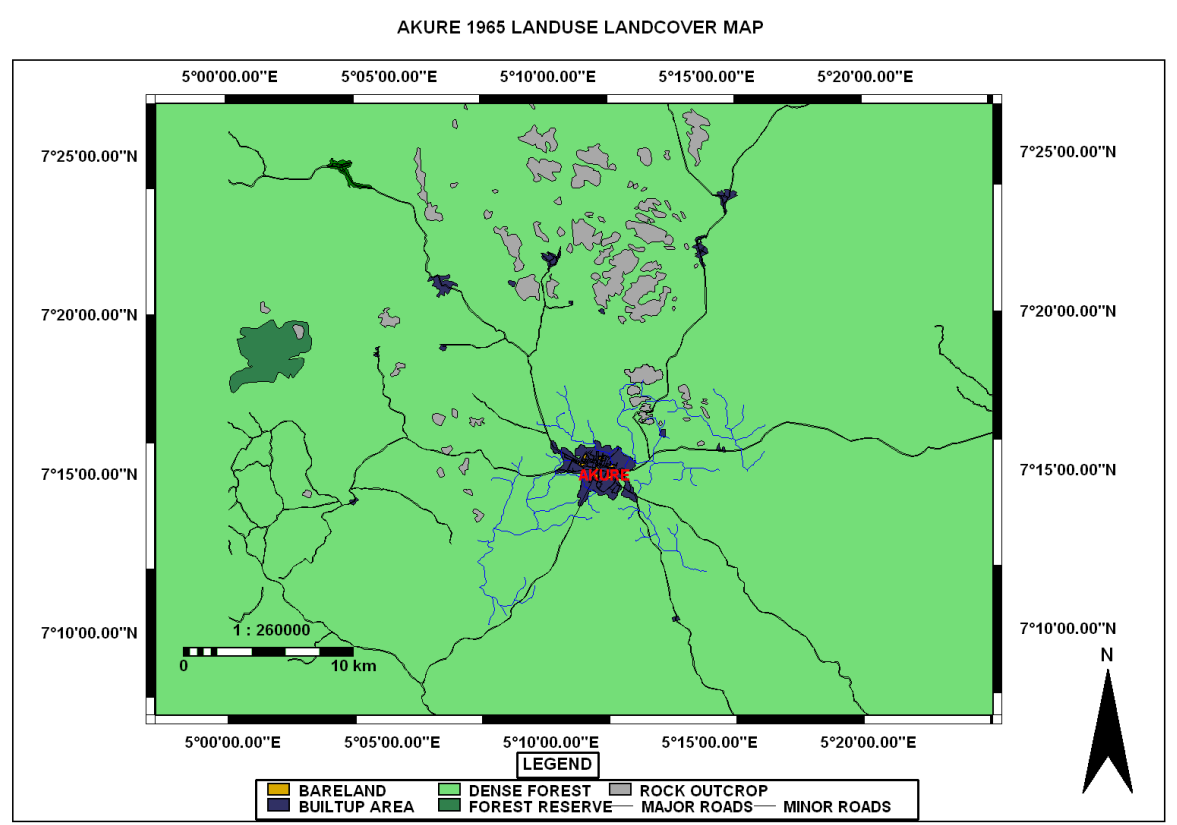

Figure 3. Landsat MSS 1972 Image of Akure produced from 1965 Topographic Map.

Fig. 4 shows the result of the image classification of 1986 LandSat TM image of Akure. The built-up area is still surrounded by the bare land which is exposed land under cultivation. There is a significant increase in the size of the built-up area from $1.0 \%$ to $2.46 \%$ as shown in table 2 .

Fig. 5 shows the landuse landcover map of the study area in 2002. It could be observed that the settlements which are referred to as built-up are still surrounded by the bare land or cultivation while the rocks remain in their original location. The vegetation is no longer concentrated as it were in 1986 while built-up areas have expanded in size. The built-up area has also increase from $2.46 \%$ to $3.90 \%$ as shown in table 2 . 


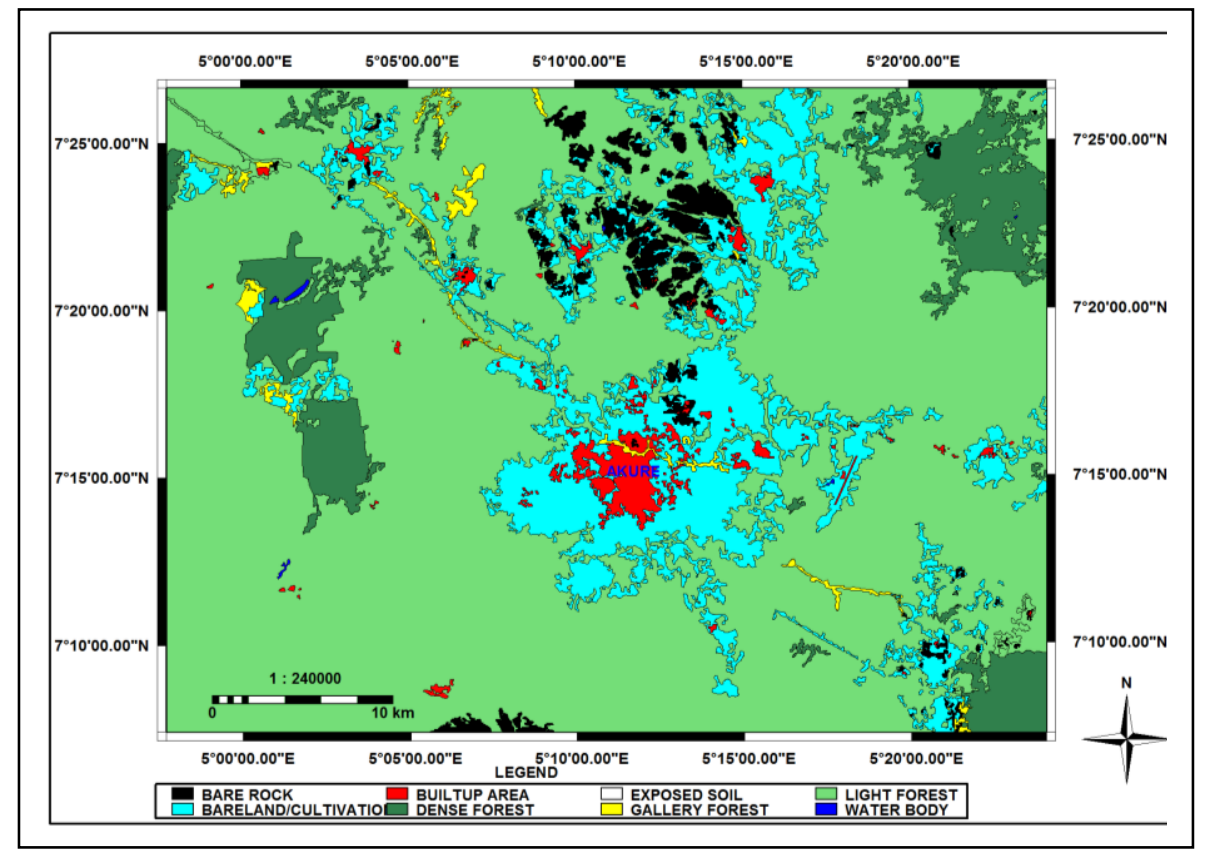

Figure 4. Supervised Classification of Landuse Landcover Map of Akure in 1986.

LANDUSE LANDCOVER MAP OF AKURE 2002

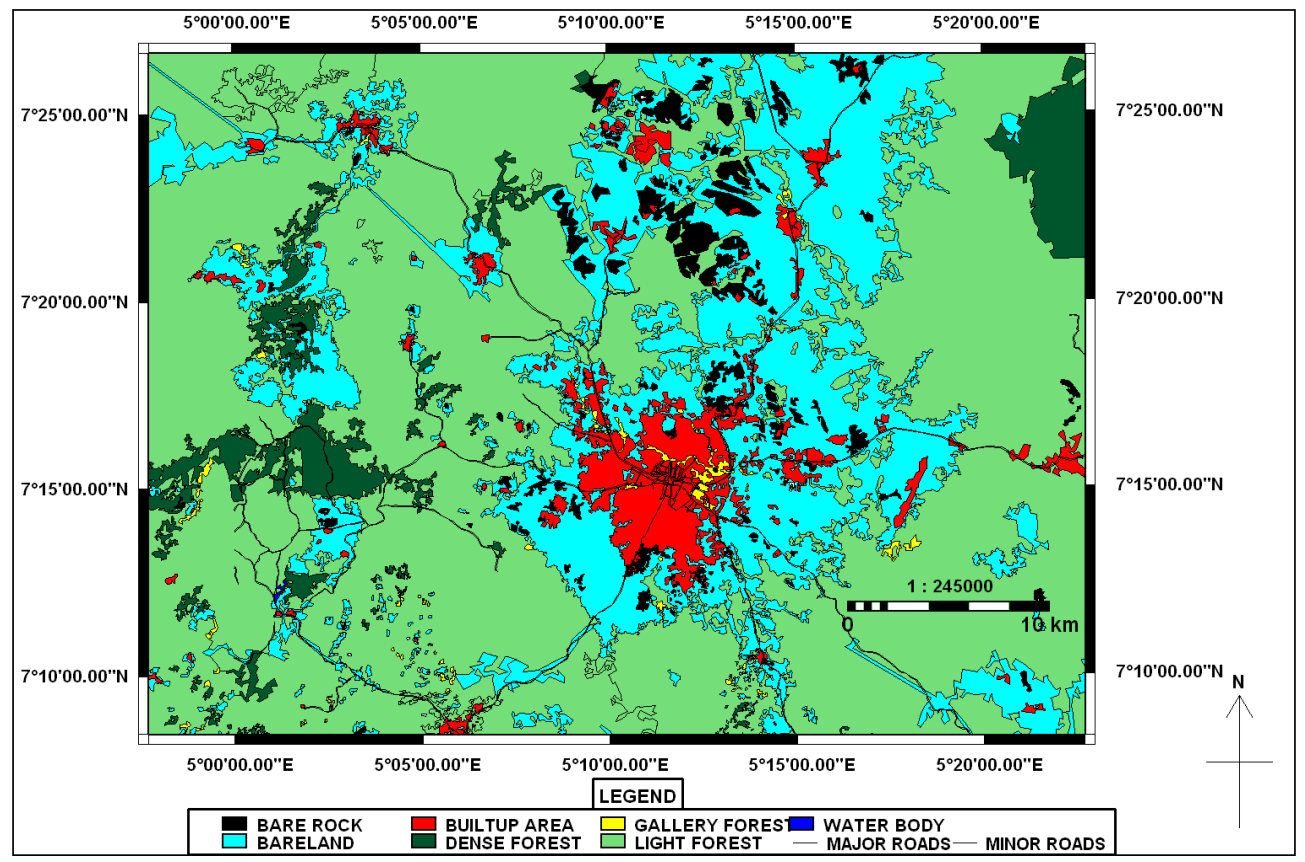

Figure 5. Supervised Classification of Landuse/Landcover of Akure in 2002.

Fig. 6 and shows the landuse/landcover of Akure in 2009 land use. The map shows that those areas that were bare land/cultivation in the 2002 land use map are now occupied with buildings in the 2009 land use map. It was also noticed that areas that were formerly vegetation has changed to light forest due to encroachment effects of development activities. Also most arable land in 2002 land use map have been taken over for residential development by 2009 thereby depriving urban dwellers spaces for urban agricultural development. This phenomenon could greatly affect the wellbeing of the people as a healthy living is a potential tool for a rapid economic development 


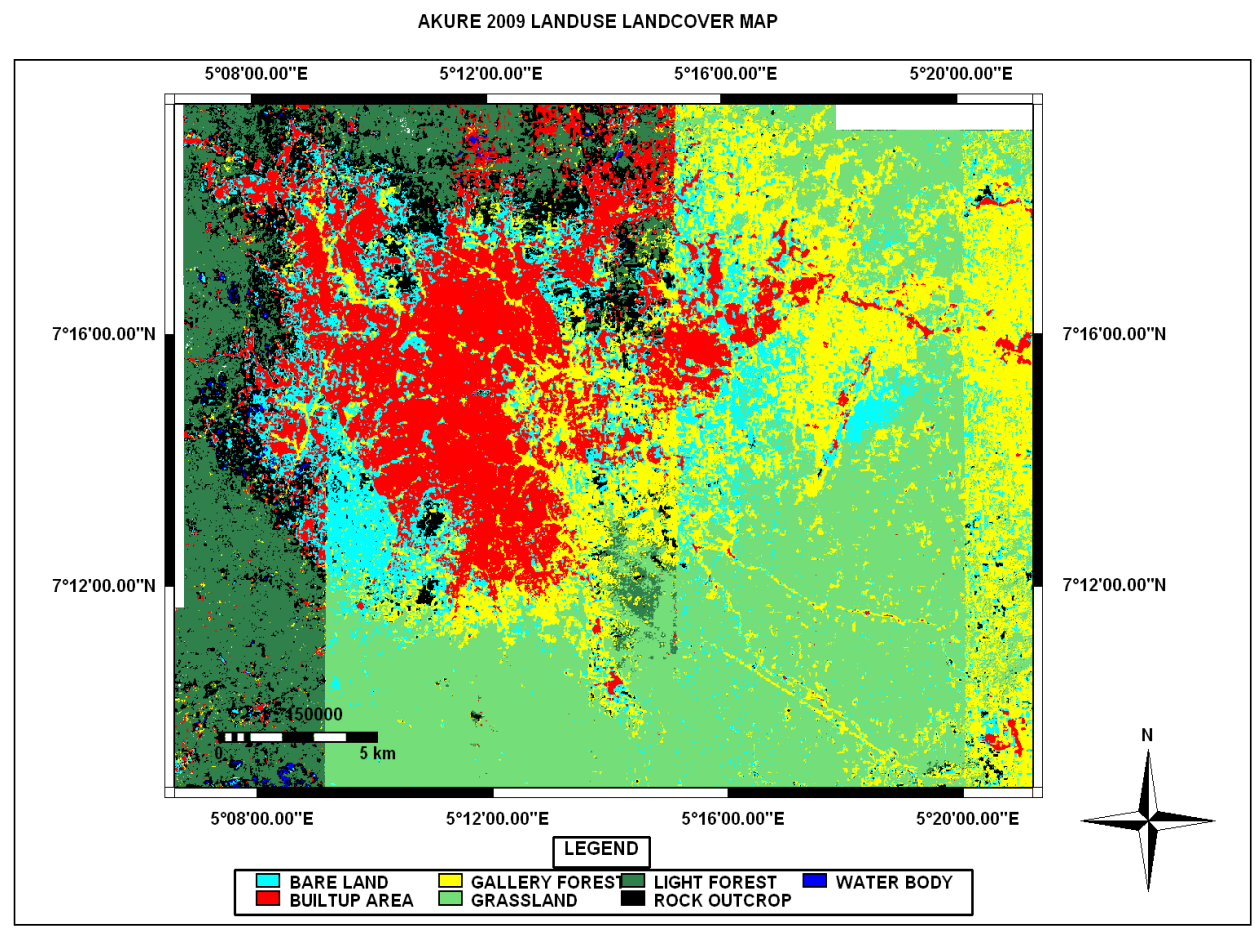

Figure 6. Supervised Classification of Landuse/Landcover of Akure in 2009.

Table 2. Main Land Cover (Ha and \%) in Akure and Environs in 1972, 1986 and 2002.

\begin{tabular}{|l|l|c|l|c|l|c|c|}
\hline \multicolumn{2}{|l|}{ Main Land Cover } & \multicolumn{2}{c|}{1972} & \multicolumn{2}{c|}{1986} & \multicolumn{2}{c|}{2002} \\
\hline Code & Class & Area (ha) & $\%$ & Area (ha) & $\%$ & Area (ha) & $\%$ \\
\hline BC & Bare land/Cultivation & 14953.40 & 15.25 & 17741.30 & 17.98 & 37277.20 & 37.78 \\
\hline BA & Built-up Area & 977.20 & 1.00 & 2431.60 & 2.46 & 3852.70 & 3.90 \\
\hline RO & Rock Outcrop & 4598.50 & 4.69 & 5002.90 & 5.07 & 8268.50 & 8.38 \\
\hline AP & Airport & 0.0 & 0.00 & 48.10 & 0.05 & 125.20 & 0.13 \\
\hline VG & Vegetation & 77547.90 & 79.07 & 75359.70 & 76.37 & 49120.60 & 49.78 \\
\hline WB & Water Body & 0.0 & 0.0 & 7.60 & 0.01 & 33.00 & 0.03 \\
\hline & Total Land Cover & 98077.0 & 100 & 98679.70 & 100 & 98677.20 & 100 \\
\hline
\end{tabular}

Source: Author's fieldwork, 2013

From Table 2, it is evident that there had been changes over the thirty-four years' period. The landcover tables and maps of 1972, 1986 and 2002 show the changes that have already occurred. For instance, in 1972, the built-up area was 977.20 hectares, in 1986 it was 2,431.60 hectares and in 2002 it grew to 3,852.70 hectares. The exposed rock in 1972 was 4,598.50 hectares, in 1986 it was 5002.90 hectares and in 2002 it was 8268.50 hectares. One major reason responsible for this was as a result of increase in the production of quarry activities during these periods. Also in 1972 bare land was 14953.40 hectares, $1,7741.30$ hectares in 1986 and 37,277.20 hectares in 2002.This increase is largely as a result of more conversion of vegetation into agricultural lands and construction purposes. Vegetation in 1972 was 77547.90 hectares, in 1986 it was 75359.70 hectares and in 2002 it decreased to 49120.60 hectares. Water bodies in 1972 were 0.00 hectare around Airport area. But in 1986, water bodies were 7.6 hectares while in 2002 it was 33.00 hectares as a 
result of one additional artificial pond in the area. All the changes in the three years period could also be seen in fig. 3, fig. 4 and fig. 5 respectively.

The urban growth rate (built-up Area) obtained in table 2 in 2002 is 3852.70ha. The predicting future trend or expansion of Akure for 2002 to 2022 using exponential model of Hoftee and Brussels (2002) is calculated by this formula:

$$
\mathrm{An}=\mathrm{Ao} * \operatorname{EXP}(\text { perc } / 100 * \mathrm{n})
$$

where: 'Ao' is the amount in year o, 'An' is the amount in n years, Perc is the growth rate as a percentage per year, ' $n$ ' is the number of years.

The expected urban growth after 20 years of a built-up area of 3852.7 ha with an estimated growth rate of $3.6 \%$ per year is: $3852.70 * \operatorname{EXP}(3.6 / 100 * 20)=5863.66$. The urban expansion in 2022 will be 5863.66 hectares. This is shown in table 3 .

Table 3. Land Cover Changes in $\mathrm{Ha} / \mathrm{Year}$ and \%/Year.

\begin{tabular}{|c|c|c|c|c|c|c|c|}
\hline \multirow[t]{2}{*}{ Year } & \multirow{2}{*}{$\begin{array}{c}\text { Land cover } \\
\text { area (ha) } \\
\text { BA }\end{array}$} & \multicolumn{2}{|c|}{ Change } & \multirow{2}{*}{$\begin{array}{l}\text { Time } \\
\text { span } \\
\text { (years) }\end{array}$} & \multicolumn{2}{|c|}{$\begin{array}{c}\text { Arithmetic mean } \\
\text { change }\end{array}$} & \multirow[t]{2}{*}{ Period } \\
\hline & & (ha) & $(\%)$ & & (ha/year) & $(\% /$ Year $)$ & \\
\hline 1972 & 977.2 & - & - & - & - & - & - \\
\hline 1986 & 2431.60 & 1454.40 & 148.83 & 14 & 103.89 & 10.63 & $1972-1986$ \\
\hline 2002 & 3852.7 & 1421.10 & 58.44 & 16 & 88.82 & 3.66 & $1986-2002$ \\
\hline 2022 & 5863.66 & 2010.96 & 52.20 & 20 & 100.55 & 2.61 & $2002-2022$ \\
\hline
\end{tabular}

Using map calculation function (iff) we can then calculate urban growth prediction modelling as: Urban growth= iff(urban72 = "urban,' ' 'urban72,', iff (urban86 = 'urban,', '"urban86,', iff (urban 2002 = "urban," ' 'urban2002,',iff (urban2022 = "urban,' ' 'urban2022,', urban2022).

The explanation of the 'iff' formulae mean: if the map urban 72 has class ' $u r b a n$, , then assign the class "urban" to the output map, 'urban growth, otherwise if map 86 has class 'urban'" then assign the class urban to the output map (urban growth) etc.

The final output would be (urban growth 72, urban growth 86, urban growth 2002 and urban growth 2022). This map urban growth is now converted to polygon map with the raster to polygon command in Integrated Land and Water Information System software (ILWIS). The final map that shows the visualization of urban growth prediction modelling is shown in fig. 7.

Fig. 7 shows the urban expansion from 1972 to 2022 using the above scenario and prediction urban modeling. It is noted that the prediction urban expansion is expected to avoid the physical obstacles of the great rocks in the study area. This prediction urban expansion model should be taken into consideration in future decision making and the implementation of the new master plan. 


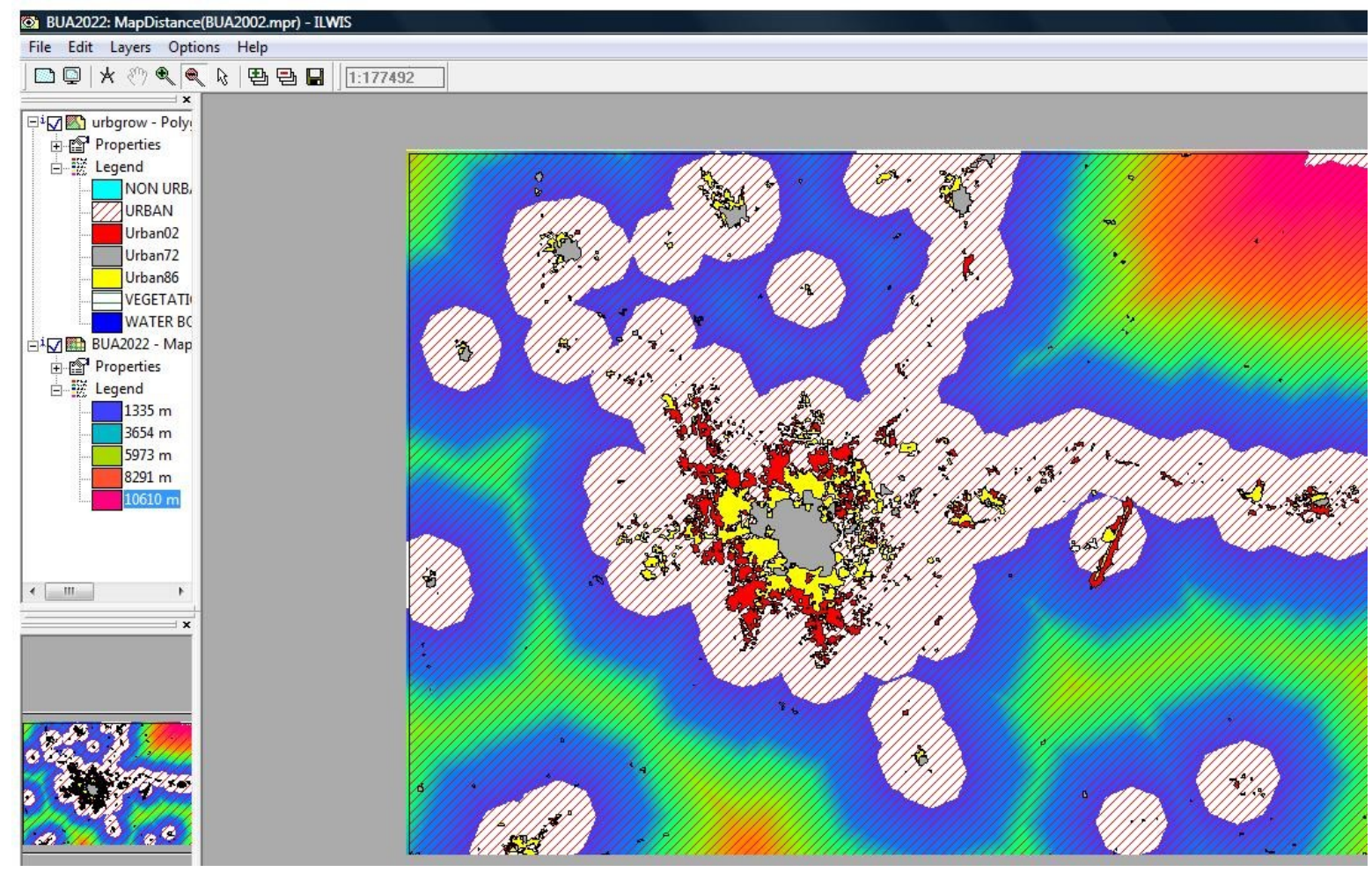

Figure 7. Prediction Modeling Urban Expansion of Akure from 1972 to 2022.

To evaluate the relationship between population growth and land use pattern particularly in the built-up area of Akure, the land area data derived from the classified imagery of the years being studied were used to determine population density of the study area. The population of Akure in 1963 and 1991 was put at 106,000 and 239,124 respectively [11]. Population projection formula $\mathrm{P}_{\mathrm{t}}$ $=\mathrm{P}_{0}(1+\mathrm{r})^{\mathrm{n}}$ was adopted to project the population of Akure from 1963 to 1972 and 1986 using population growth rate $(\mathrm{r})$ of $1.3 \%$ per year while the population census result of 1991 was used to determine the population of Akure in 2002 and 2009 using population growth rate of $2.77 \%$ per year. These rates gives the population census result figures of Akure for $1986(144,544)$ and 2006 $(360,268)$ [7-8] when used to project from 1963 and 1986 respectively using the projection formula.

Table 4 shows the trends of population growth of Akure during the period of study using the built-up area derived from the classified satellite imagery and the population data of Akure from the National Population Commission. The data shows that within the space of 16 years population density in Akure reduced from 3.43 persons per $\mathrm{m}^{2}$ per year in 1986 to 1.81 density in 2002 per year. This shows that built-up area increased more rapidly than population growth in the study area leading to the decrease in density per year during the period while increase in density from 1.81 in 2002 to 0.14 in 2009 shows that population increased at a lower rate than the rate of urban expansion from 2002 and 2009.

Table 4. Trends of Population Growth in Akure, 1965-2013.

\begin{tabular}{|c|c|c|c|c|}
\hline Year & Population & $\begin{array}{l}\text { Built-up area } \\
\left(\mathrm{m}^{2}\right)\end{array}$ & $\begin{array}{c}\text { Population density } \\
\left(\text { Persons per } \mathbf{m}^{2}\right)\end{array}$ & $\begin{array}{c}\text { Density per } \\
\text { year }\end{array}$ \\
\hline 1963 & 106,774 & $1,3449353.25$ & 124 & - \\
\hline 1986 & 142,991 & 27972003.98 & 196 & 3.43 \\
\hline 2002 & 313,751 & 70585829.28 & 225 & 1.81 \\
\hline 2009 & 391,037 & 883908908.00 & 226 & 0.14 \\
\hline
\end{tabular}

Source: Classified satellite imagery and NPC census results, 2006 


\section{Planning Implications of Urban Expansion}

Rapid urbanization and industrialization have resulted in sharp land cover changes. Land cover change could be regarded in biotic diversity, actual and potential productivity, soil fertility or quality, and run-off sedimentation rates which is greatly affected by landuse change [20].

The search for better economic opportunities and higher incomes were the primary reasons for the growth of the city. The change in status of Akure city to provincial headquarters in 1915 enhanced its social and economic development and consequently initiated massive land use changes. There are new administrative offices and important and improved infrastructures. More health facilities, schools and other public institutions came into existence. With the creation of more states in 1976, Akure was elevated into a state capital and modern administrative physical structures emerged. People moved from rural to city. Population increased tremendously. More institutions were built, educational, health, religion, and military. Others include Tele-communication, Agriculture, and Police. More transport routes, housing complexes, hotels and recreational facilities were introduced so also was financial houses. All these transformed Akure within a relatively short period from Agricultural town to an important urban centre [21].

The 1973 population census put Akure's population at approximately 91,022 and this rose to 125,477 people in $1986,177,297$, people in 2000 and finally to 340,021 people in 2006 [22]. This rapid urban population growth reflects a natural population increase among the urban residents as well as migration of people from rural areas to the city. Growth was faster in the 2000 than between 1972 and 1986. Looking at these population figures, the substantial population growth in Akure area during the past 30 years is partly responsible for the landuse changes.

In Akure the housing situation has also been very revealing. There is a total residential house stock in Akure before it became the state capital in 1976. Since 1976, there has been wide spread of housing units at periphery due to urban growth and civilization. Between 1976 and 1986, people living in Akure enjoyed accommodation facilities put across by the State and Federal Governments at affordable cost. These affordable houses (estates) were cut short which caused serious shortage of accommodation hence people decided to build their own houses to rent them in order to generate income for themselves and this brought about increase in the built-up areas.

The urban expansion of the city of Akure revealed in this study occurred as a result of a number of possible forces that have been elaborated below:

Table 5 shows that residential use has the highest percentage in all the landuses. Erekesan/Erekafa constitute about 53.4 percent of the total may be regarded as the most densely built-up areas of the town. Isinkan/ Ondo road and Ijoka/ Sijuwade accounted for $40.6 \%$ and $44.3 \%$ of the total residential accommodations respectively. These groups gradually developed after the evolution of Erekesan/ Erekefa while Federal Housing (Shagari village) contains 57.8 percent of the total may be regarded as the recent developments in the outskirts. As better building space standards and regulations are observed in the outskirts, the buildings are no longer nucleated as in the Erakesan/ Erekefa. Generally, the growth of residential landuse in Akure is due to rapid influx of immigrants into the city which in turns increase the demand for residential landuse.

In educational use, 9.2\%, 8.5\% can be found in Erekesan/ Erekefa and Isinkan/ Ondo road while $4.7 \%, 4.0 \%$ are found in Ijoka/ Sijuwade and Federal Housing (Shagari Village). This implies that some higher institutions of learning such as Federal University of Technology, Akure, College of Agriculture, School of Nursing and some private secondary schools, have attracted a large area of land thereby contributing to population growth which has directly and indirectly influenced other landuse activities in their surroundings.

In case of transportation landuse the growth of Akure has been along the major communication routes from the centre into the outskirts as seen in table 4 where this landuse in Erekesan/ Erekefa is 5.2\% and in Federal Housing (Shagari village) 5.8\%. All these roads move in the location direction of different service facilities such as banks, petrol stations, post offices and other services.

In terms of Agricultural and Industrial landuse Federal housing (Shagari village) recorded $2.3 \%$ and $2.9 \%$ respectively. This implies that agricultural and industrial landuses are located at the 
outskirt of the town. Also as regards health uses table 4 revealed that most of the hospitals (private) are located and scattered in converted residential apartments, while the State hospital is located at the outskirt of the town.

All other various categories of building such as religion, cemetery, abattoir; government, culture, tradition and civic have either directly or indirectly influenced landuse activities in the study area as shown in table 5.

Table 5. Category of Building /Property in the Study Area.

\begin{tabular}{|l|c|c|c|c|}
\hline \multicolumn{1}{|c|}{ Types of use } & $\begin{array}{c}\text { Erekesan/ } \\
\text { Erekefa } \\
\text { \% }\end{array}$ & $\begin{array}{c}\text { Isinkan/ } \\
\text { Ondo Road } \\
\text { \% }\end{array}$ & $\begin{array}{c}\text { Ijoka/ } \\
\text { Sijuwade } \\
\text { \% }\end{array}$ & $\begin{array}{c}\text { Federal Housing } \\
\text { (Shagari Village) } \\
\text { \% }\end{array}$ \\
\hline Educational & 9.2 & 8.5 & 4.7 & 4.0 \\
\hline Health & 7.5 & 5.2 & 1.9 & 2.6 \\
\hline Residential & 53.4 & 40.6 & 44.3 & 57.8 \\
\hline Religious & 6.6 & 9.8 & 10.1 & 8.7 \\
\hline Cementry & 2.7 & 1.1 & - & 1.7 \\
\hline Industrial & 0.5 & 3.3 & 5.1 & 2.3 \\
\hline Abator & 1.1 & 2.2 & - & 2.3 \\
\hline Government & 1.2 & 4.3 & 9.8 & 2.3 \\
\hline Commercial & 3.2 & 7.6 & 3.8 & 5.8 \\
\hline Agriculture & 1.0 & 3.3 & 3.8 & 0.2 \\
\hline Transportation & 5.2 & 6.5 & 8.9 & 0.6 \\
\hline Civic & 2.2 & 2.2 & 1.3 & 0.6 \\
\hline Cultural/Tradition & 6.2 & 5.4 & 2.5 & 3.8 \\
\hline Other specify & - & - & & 2.9 \\
\hline
\end{tabular}

Source: Author's field work, 2013

Table 6 shows the landuse directed to educational use. As can be seen from the table, $18.6 \%$ are devoted to primary education in Erekesan/ Erekefa, 22.8\% in Isinkan/ Ondo road, 17.1\% in Ijoka/ Sijuwade and 11.6\% in Federal Housing (Shagari Village). The secondary educational use was also found in Erekesan/ Erekefa with 20.6\%, 13.0\% in Isinkan/ Ondo road, 7.0\% in Ijoka/ Sijuwade while $6.4 \%$ are recorded for secondary educational land use in Federal Housing/ (Shagari Village). The tertiary educational landuse are generally, low in all the educational landuses, as only $2.7 \%$ are found in Isinkan/ Ondo road, $0.6 \%$ in Ijoka/ Sijuwade and 17.9\% in Federal Housing/ (Shagari Village). It must be stated that educational uses were spatially distributed all over the area. As the need for more institutions increases, the area extent in each zone increases outwardly, for example the establishment of Federal University of Technology, School of Nursing, School of Agriculture all of which are found at the outskirts of the town because of their land cover area which demands for large or an extensive area. 
Table 6. Educational Use in the Study Area.

\begin{tabular}{|l|c|c|c|c|}
\hline $\begin{array}{c}\text { Types of } \\
\text { Institution }\end{array}$ & $\begin{array}{c}\text { Erekesan/Erekefa } \\
\%\end{array}$ & $\begin{array}{c}\text { Isinkan/Ondo } \\
\text { Road } \%\end{array}$ & $\begin{array}{c}\text { Ijoka/ Sijuwade } \\
\%\end{array}$ & $\begin{array}{c}\text { Federal Housing } \\
\text { (Shagari Village) } \%\end{array}$ \\
\hline Primary & 18.6 & 22.8 & 17.1 & 11.6 \\
\hline Secondary & 20.6 & 13.0 & 7.0 & 6.4 \\
\hline Tertiary & - & 2.7 & 0.6 & 17.9 \\
\hline Others & 60.8 & 61.4 & 75.3 & 64.1 \\
\hline
\end{tabular}

Source: Author's field work, 2013

All lands not utilized for residential, commercial, industrial, educational, and recreational and road networks are virtually agricultural land. In table 7 , we can find vacant lands here and there occupied by farming types. This is mostly common in Federal Housing (Shagari Village) where cash cropping, arable cropping, animal husbandry all accounted for $28.3 \%$, vegetable farming $13.3 \%$, fish farming $1.7 \%$ and forestry $0.6 \%$. One of the constraints to urban development is the serious urban encroachment on good agricultural lands. The mere fact that little or no consideration is given to the agricultural potentials of any piece of land before it is taken over by urban uses, makes good agricultural land susceptible to unlimited urban encroachment. There is therefore the need to preserve some green but not only to break the monotony of continuous urban growth but also to be utilized for intensive farming to feed the teeming urban population.

Table 7. Types of Urban Agriculture in the Study Area.

\begin{tabular}{|l|c|c|c|c|}
\hline \multicolumn{1}{|c|}{$\begin{array}{c}\text { Types of } \\
\text { Agriculture }\end{array}$} & $\begin{array}{c}\text { Erekesan/ } \\
\text { Erekefa } \\
\%\end{array}$ & $\begin{array}{c}\text { Isinkan/ Ondo } \\
\text { Road } \\
\%\end{array}$ & $\begin{array}{c}\text { Ijoka/ } \\
\text { Sijuwasde } \\
\%\end{array}$ & $\begin{array}{c}\text { Federal Hosing } \\
\text { (Shagari Village) } \\
\%\end{array}$ \\
\hline Cash cropping & - & - & 8.9 & 9.8 \\
\hline Arable cropping & - & - & 8.9 & 9.8 \\
\hline Animal husbandry & 4.1 & 0.9 & 19.7 & 8.7 \\
\hline Vegetable farming & - & - & 2.5 & 13.3 \\
\hline Fish farming & - & 0.5 & 1.3 & 1.7 \\
\hline Forestry & - & - & - & 0.6 \\
\hline Others & 1.0 & - & - & \\
\hline
\end{tabular}

Source: Author's field work, 2013

\section{Conclusions and Recommendations}

The study has highlighted the possible forces of urban expansion in Akure city, and its implications on the people living in the city. It has also identified some of issues that have contributed to the high incidence of landuse changes in the study area. Some of these are the better economic opportunities, urban migration, increasing in higher institutions of learning, being a state capital amongst others have contributed to high rate of urban expansion in the study area.

From the GIS outputs, the results show that Akure town has increased by 3852.70 ha over the period from 1986 to 2002, representing an increase in area coverage of over $88.820 \%$. Loss of forests and the problem of urban sprawl have accompanied the urban expansion. Spatial expansion directions have changed over the period. The North-East expansion, witnessed in the $1972-1986$ was followed by both north west and part of South East expansion during the 1986 to 2002 period. The analysis of the urban sprawl directions and landcover conversion indicated that the city has experienced growth within the period of time hence the city needed extra ability to manage the 
available resources effectively. The study therefore advances some recommendations as a way of checking this urban expansion in the study area.

The land acquisition in the built-up area should be regulated. All available spaces that were covered with residential building should be regulated to ensure the allocation of space for other essential activities such as community services, transportation, recreation and commercial facilities.

From the field survey, most housing developments emerged between 1986 and 2002.Although the period 1972 - 1986 witnessed an unprecedented upsurge in home building, most of these houses have become dilapidated. Property rehabilitation programmes in the slums of Akure town can have a useful function since a fairly large proportion of housing in the study area can be improved by re-roofing, encaging windows, painting and sanitary improvements.

In order to control and mitigate the negative outcomes of urban expansion, adequate and efficient development plan should focus on ways to sustain the present and future needs of the society through sustainable development. The essence of sustainable development is to encourage development in a way which will not damage our environment. This can only be achieved by taking an inventory of the available resources and planning for their present and future use. Therefore, in order to manage urban expansion in a sustainable manner, expansion must be adequately monitored. As for encroachment on agricultural land, people should be encouraged to first fill in the gap within the town before extending or moving to the outskirt, this would reduce the way some of the agricultural soils are being eaten up by urban land. It is also necessary to set limit to urban expansion through creation of green belt round the city of Akure.

\section{References}

[1] A.T. Adebayejo, O. Abolade, Analysis of spatial changes in Ogbomoso City, Journal of the NITP. 19(1) (2006) 35-47.

[2] A.L. Mabogunje, Health Challenges of Nigerian urbanization, a Nigeria Tribune, $15^{\text {th }}$ January, 2007, p.42.

[3] G. Owusu, Social effect of poor sanitation and waste management on poor urban communities: a neighbourhood-specific study of Sabon Zongo, Accra, Journal of Urbanism. 3(2) (2010) 145-160.

[4] E.M. Brennan, Population, urbanization, environmental and security: a summary of the issues, Environmental Change and Security Project Reports. 5 (1999) 4-14.

[5] O.A. Olotu, Municipal solid waste management in Nigerian towns. A case study of Akure Metropolis, Unpublished B. Tech. Dissertation, Urban and Regional Planning Department, Federal University of Technology, Akure, Nigeria, 2005.

[6] National Population commission, Population of the Federal Republic of Nigeria, 1991.

[7] L. Merrill, Managing Cities as drivers of the economy, a case study of Asian cities, 2006.

[8] N. Musaogwu et al., A case study of using remote sensing data and GIS for land management. Catalca region. FIG XXII International Congress USA, Washington, D.C. U.S.A., April 1926, 2002.

[9] B. Cohen, Urban growth in developing countries: a review of current trend and a caution regarding existing forecasts, World Development. 32(1) (2006) 23-51.

[10] United Nations Centre for Human Settlements (HABITAT), An urbanizing world: global report on human settlements, Oxford University Press for HABITAT, 2001.

[11] E.H. William, An introduction to urban geographical information systems, Oxford University Press. 1991. 
[12] A.G. Onokerhoraye, G.E.D. Omuta, Urban Systems and planning. The Geography and Planning Series, Benin, University of Benin Nigeria, 1985.

[13] R.E. Elnazir, F. Xue-zhi, C. Zheng, Satellite remote sensing for urban growth assessment in Snaoxing City, Zhegiang Province, J. Zhegiang Univ. Sci. 5(9) (2004) 1095-1101.

[14] L. Sedigheh, Remote sensing for urban growth in Northern Iran, $22^{\text {nd }}$ Asian Conference on Remote Sensing, 5-9 Nov. 2001, Singapore.

[15] M.S. Moeller, Remote sensing for monitoring of urban growth pattern, in: Proc. ISPRS joint conference: $3^{\text {rd }}$ International Symposium Remote Sensing and Data Fusion Over Urban Areas and 5th International Symposium Remote Sensing of Urban Areas, Tempe, AZ, USA, 14-16 March 2005.

[16] K. Rao, Remote sensing for land use planning, International Journal of Remote Sensing. 16 (1995) 52-60.

[17] R.E. Ekpenyong, Analysis of findings from the Akwa Ibom State landuse/land cover change early warning system, Nigerian Journal of Geography and the Environment. 1 (2008) 68-76.

[18] U. Fanan, K. Dlama, O. Ifatimehin, Urban expansion and vegetal cover loss in and around Nigeria's Federal Capital City, Journal of Ecology and the Natural Environment. 3(1) (2010) $1-10$.

[19] E. Okoko, Quantitative Techniques in Urban Analysis, Akure Kraft Books Limited, 2000.

[20] W.L. Steffen et al., Global change and terrestrial ecosystem. The operational plan, IGBP report No 21, International geosphere-Biosphere Program, Stockholm, 1992.

[21] A.O. Atanlode, Urban Landuse change and its effect on Residential Landuse. A case study of Akure City, Unpublished B. Tech. Dissertation, Urban and Regional Planning Department, Federal University of Technology, Akure, Nigeria, 2001.

[22] National Population Commission, Population of the Federal Republic of Nigeria. Analytical Report at the National Level, Abuja, Nigeria, 2006. 